\title{
Pelatihan Komputer Untuk Administrasi Dan Keuangan Pegawai Kelurahan Desa Tegalrejo Kecamatan Tengaran Kabupaten Semarang
}

\author{
Ulfah Mediaty Arief ${ }^{1}$, Sri Sukamta ${ }^{2}$ \\ ${ }^{1,2}$ Fakultas Teknik, Universitas Negeri Semarang \\ Kampus Sekaran Telepon +6224-8508105 \\ e-mail: ulfahmediatyarief@mail.unnes.ac.id', ssukamta2014@gmail.com²
}

\begin{abstract}
Abstrak
Berkembangnya teknologi elektronika, khususnya adanya komputer akan menyebabkan perkembangan teknologi sistem pada bidang pekerjaan administrasi dan pengelolaan keuangan di berbagai instansi atau perkantoran, mulai dari pekerjaan administrasi dan laporan keuangan yang ringan sampai yang rumit sehingga pekerjaan lebih efektif dan efisien. Pegawai kelurahan mempunyai pekerjaan yang selalu melayani masyarakat disekitar kelurahan tersebut yang berhubungan dengan administrasi dan keuangan. Pegawai Kelurahan Tegalrejo Kecamatan Tengaran Kabupaten Semarang adalah obyek dan subyek pegabdian kepada masyarakat. Pegawai Kelurahan Tegalrejo mempunyai pengetahuan tentang komputer rata-rata masih kurang atau hampir tidak ada (10\%) pada saat pre test, sedangkan pekerjaan yang dilakukan adalah administrasi yang selama ini dilakukan dengan manual. Untuk itu dalam Kegiatan Pegabdian pada Masyarakat yang dilakukan saat ini yaitu pelatihan komputer menggunakan microsoft windows dan microsoft word untuk pegawai Kelurahan Tegalrejo. Tujuan yang ingin dicapai dalam pegabdian kepada masayarakat ini yaitu dapat menggunakan Program Microsoft Word dan Microsoft Exell dalam mengolah pekerjaan administrasi dan Keuangan yang ada pada Kelurahan Tegalrejo.Metode yang dilakukan dalam kegiatan ini adalah ceramah, pelatihan, dan diskusi. Setelah selesai dilakukan pelatihan maka nilai post-test yang didapatkan rata-rata $83.1 \%$. Pelatihan komputer oleh tim pengabdian pada masyarakat Unnes sangat diharapkan dalam peningkatan kinerja pegawai Kelurahan Tegalrejo Kecamatan Tengaran Kabupaten Semarang.
\end{abstract}

Kata kunci : Peningkatan, Pelatihan, Komputer

\section{PENDAHULUAN}

Desa Tegalrejo memiliki wilayah cukup luas sekitar 2, $15 \mathrm{Km}^{2}$ dan terbagi dalam 11 RW dan 22 RT. Desa Tegalrejo terbagi dalam 6 Dusun ${ }^{[2]}$ yaitu : Dusun Tegalrejo, Kalisoko Lor, Kalisoko kidul, Doso Warung, Ngesrep, Tlatar. Kelurahan Tegalrejo Kecamatan Tengaran adalah wilayah Kabupaten Semarang yang terletak kurang lebih $50 \mathrm{Km}$ dari Unnes ${ }^{[2]}$. Kantor Kelurahan ini mempunyai jumlah pegawai kira-kira 10 Orang, dengan latar belakang pendidikan berbagai jenjang / tingkat pendidikan. Kelurahan Tegalrejo menjadi suatu kelurahan yang cukup ramai aktifitas administrasinya di salah satu kabupaten Semarang yang berada di Kecamatan Tengaran. Adapun berapa pekerjaan Administrasi dan laporan keuangan yang cukup banyak dikelurahan tersebut masih menggunakan manual (tanpa komputer) Sehingga dapat memperlambat kinerja ${ }^{[1]}$ penyelesaian Laporan administrasi dan 
keuangan yang begitu padat . Pada gambaran kondisi, maka dapat diidentifikasikan permasalahan di Kelurahan desa Tegalrejo sebagai berikut:

1. Adanya kemajuan teknologi elektronik khususnya komputer ${ }^{[1]}$.

2. Kurangnya pengetahuan dan keterampilan tentang penggunaan komputer untuk membantu pengolahan administrasi dan keuangan yang dimiliki oleh istansi perkantoran khususnya pegawai kelurahan Tegalrejo Kecamatan Tengaran Kabupaten Semarang

Berdasarkan permasalahan diatas maka tujuan yang ingin dicapai dalam kegiatan pengabdian kepada masyarakat ini ialah agar masyarakat peserta dapat :

1. Memiliki pengetahuan tentang penggunaan komputer ${ }^{[3]}$

2. Menggunakan Program Microsoft Windows dan Microsoft Word dan Microsoft Exell dalam mengolah pekerjaan administrasi dan keuangan dalam pelayanan masyarakat yang ada pada Kelurahan Tegalrejo Kecamatan Tengaran Kabupaten Semarang.

3. Meningkatkan Kinerja Pegawai Kelurahan Tegalrejo Kecamatan Tengaran Kabupaten Semarang dalam menggunakan komputer ${ }^{[1]}$.

Dilaksanakannya pengabdian pada masyarakat ini diharapkan dapat memberikan manfaat :

1. Adanya peningkatan pengetahuan dan keterampilan tentang komputer utamanya pada cara penggunaan Program Microsoft Windows dan Microsoft Word sesuai dengan kebutuhan administrasi. ${ }^{[5]}$

2. Masyarakat sasaran dapat menggunakan dan memamfaatkan komputer dengan cara yang benar dan optimal sesuai dengan kepentingan mereka.

3. Terciptanya jalinan kerjasama yang positip antara lembaga dan lingkungan masyarakat terutama Kelurahan Tegalrejo Kecamatan Tengaran Kabupaten Semarang dan sekitarnya khususnya pegawai kelurahan dengan LP2M Universitas Negeri Semarang.

Jurusan Teknik Elektro FT Unnes sebagai salah satu lembaga pendidikan tinggi yang memiliki kualifikasi dosen maupun teknisi yang memadai untuk menyelenggarakan pelatihan komputer menggunakan Microsoft Windows dan Microsoft Word dan Microsoft Exell di Kelurahan Tegalrejo, sehingga dapat meningkatkan kinerja dari pegawai kelurahan untuk menyelesaikan pekerjaan administrasi dan Keuangan dalam pelayanannya bagi masyrakat sekitarnya.

\section{METODE}

Metode yang akan digunakan dalam melaksanakan kegiatan pengabdian kepada masyarakat ini, ialah :

\subsection{Metode Pengabdian \\ 1. Ceramah \\ 2. Tanya jawab \\ 3. Diskusi \\ 4. Demonstrasi \\ 5. Praktek/Pelatihan}

\subsection{Rancangan Evaluasi}

Evaluasi keberhasilan kegiatan dirancang sebagai berikut :

1. Untuk mengetahui seberapa jauh pengetahuan dan wawasan peserta mengenai komputer, Program Microsoft Windows dan Microsoft Word dan Microsoft Exell maka dilakukan pre-test berupa mengaktifkan komputer, pengetahuan tentang Program Microsoft Windows dan Microsoft Word dan Microsoft Exell kepada para peserta.

2. Untuk mendapatkan gambaran keberhasilan penyampaian materi pengabdian yang telah dilaksanakan, diadakan post-test dan pengamatan untuk mengetahui peningkatan pengetahuan dan keterampilan peserta tentang pembuatan administrasi dan pengelolaan 
keuangan kantor dengan menggunakan Program Microsoft Windows dan Microsoft Word dan Microsoft Exell.

\section{HASIL DAN PEMBAHASAN}

Beberapa langkah kegiatan yang dilakukan dari Tim Pegabdian Kepada Masyarakat yaitu "Pelatihan Komputer Untuk Pegawai Kelurahan Tegalrejo Kecamatan Tengaran Kabupaten Semarang" yang dimulai tahap sosialisasi, dan tahap kedua pendaftaran peserta yang ikut pelatihan kemudian pengembangan bahan ajar/materi yang akan diberikan serta melakukan evaluasi hasil pelatihan. Banyaknya peserta yang berminat dan aktif pada hari pertama/pelatihan sebanyak 13 orang kemudian dan peserta mengharapkan sebanyak 8 kali pertemuan untuk bisa menggunakan komputer sebagai peningkatan kinerja kelurahan. Pelatihan dilakukan di kantor Kelurahan Tegalrejo Kecamatan Tengaran Kabupaten Semarang”, seperti pada gambar1.
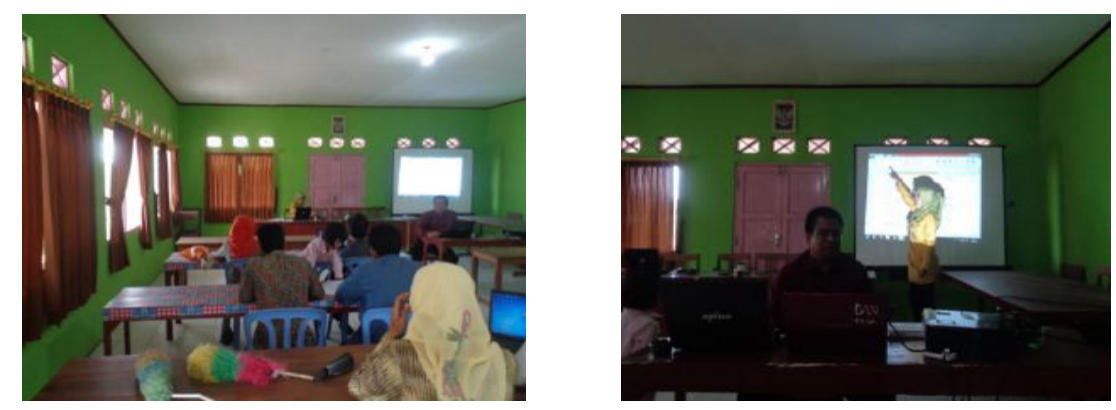

Gambar1. Memberikan Pelatihan Microsoft Word dan Microsoft Excell

\subsection{HASIL EVALUASI}

Pada saat pelaksanaan kegiatan dilakukan evaluasi yang meliputi pre-test dan post test serta pengamatan langsung penguasaan praktek seperti pada gambar 2 .
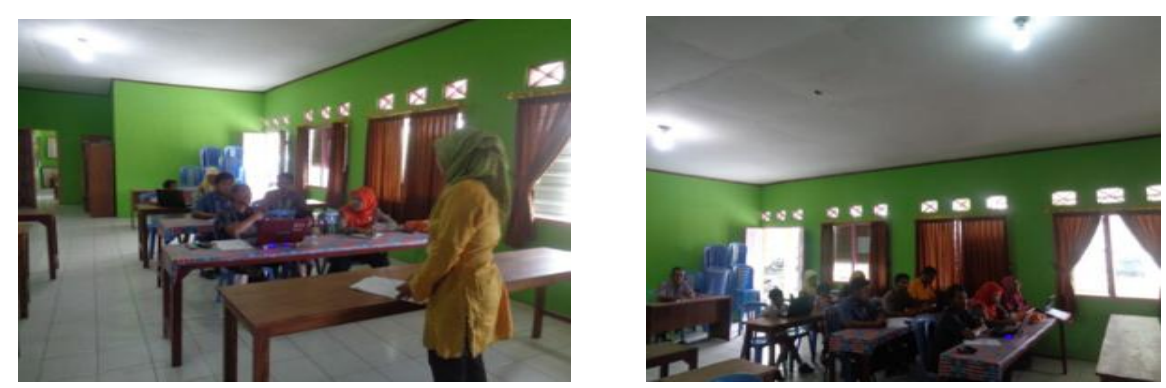

Gambar2. Melakukan Evaluasi hasil pelatihan

Kegiatan Pelatihan Komputer Untuk Pegawai Kelurahan Tegalrejo KecamatanTengaran Kabupaten Semarang telah selesai dilaksanakan dengan hasil yang memuaskan. Hal ini dapat dilihat dan ditunjukkan minat peserta untuk hadir dalam kegiatan pelatihan. Adanya peningkatan pengetahuan tentang komputer yaitu Microsoft Windows, Microsoft Word dan Microsoft Excell yang dapat diukur dari pre test dan post test seperti pada tabel 1. 
Tabel 1. Hasil Pre Test dan Post Test pada Pelatihan Komputer Pegawai Kelurahan Kecamatan Tengaran Kabupaten Semarang

\begin{tabular}{clccc}
\hline No. & Nama & Pre Test & Post Test & $\begin{array}{c}\text { Pengamatan Di } \\
\text { akhir Kegiatan }\end{array}$ \\
& & & & \\
\hline 1 & Sutarsono & 10 & 75 & Baik \\
2 & Giyarta & 20 & 80 & Baik \\
3 & Minarto & 10 & 75 & Baik \\
4 & Sutirto & 10 & 75 & Baik \\
5 & Nur Kholis & 10 & 75 & Baik \\
6 & Marsiti & 10 & 75 & Baik \\
7 & Sudarmi & 20 & 80 & Baik \\
8 & M.Jamhuri & 10 & 75 & Baik \\
9 & Jubaedi & 10 & 75 & Baik \\
10 & Warsono & 10 & 75 & Baik \\
11 & Sunarno & 20 & 80 & Baik \\
12 & Sudirjo & 10 & 75 & Baik \\
13 & Haryanto & 10 & 75 & Baik \\
& & 160 & 990 & \\
\hline
\end{tabular}

Berdasarkan data tabel 1 maka didapatkan peningkatan rata rata 83,1\%. Adanya pengabdian berupa pelatihan yang diselenggarakan oleh tim pengabdian Teknik Elektro Unnes memberikan mamfaat dalam meningkatkan pengetahuan dan keterampilan menggunakan komputer untuk administrasi dan keuangan yang dimiliki oleh pegawai Kelurahan Tegalrejo KecamatanTengaran Kabupaten Semarang dan dapat diambil mamfaat yang sebesar-besarnya untuk meningkatkan kulitas pelayanan Kelurahan terhadap masyarakat.

Keberhasilan dari pelatihan ini karena adanya motivasi yang tinggi dari peserta untuk mengikuti pelatihan dan kerja sama yang baik dari semua tim pelaksana pengabdian ini, dan cukupnya perangkat komputer/laptop yang tersedia sehingga pelatihan pada pegabdian ini berjalan dengan lancar.

\section{KESIMPULAN}

1. Kegiatan Pelatihan Komputer Untuk Pegawai Kelurahan Tegalrejo KecamatanTengaran Kabupaten Semarang telah berhasil dilaksanakan oleh Tim Pengabdian Unnes yang diukur dari hasil pretest dan posttest dengan memperoleh hasil peningkatan rata rata $83,1 \%$.

2. Pegawai Kelurahan Tegalrejo Kecamatan Tengaran Kabupaten Semarang yang mengikuti pelatihan dalam kegiatan pegabdian ini sangat bersemangat untuk melakukan latihan tahap demi tahap. 
3. Kegiatan pegabdian ini, dengan memberikan pelatihan Microsoft Windows, Microsoft Word dan Microsoft Excell maka seluruh pegawai kelurahan akan bertambah wawasan dan keterampilannya dalam meningkatkan kinerja masing-masing pegawai Kelurahan Tegalrejo KecamatanTengaran Kabupaten Semarang

\section{SARAN}

1. Pelatihan yang telah diberikan seharusnya diaplikasikan langsung setiap saat oleh pegawai kelurahan sehingga tidak lupa.

2. Pelatihan ini dapat dilanjutkan dengan pelatihan penggunaan komputer dengan internet sehingga kinerja pegawai semakin meningkat sesuai dengan perkembangan teknologi

\section{UCAPAN TERIMA KASIH}

Penulis mengucapkan terima kasih kepada DIPA Uninersitas Negeri Semarang yang telah memberi dukungan financial terhadap kegiatan Pengabdian Masyarakat

\section{DAFTAR PUSTAKA}

[1] Dewan Pelawi ,Perancangan Sistem Administrasi Siswa : Studi Kasus Pada Intensive English Course Di Jakarta ,Tesis, 2013

[2] http://www.semarangkab.go.id/skpd/bappeda/images/dokumen/statistik/dsk2015/dsk201 5 _tengaran_kabsmg.pdf

[3] Hernawan Sulistyanto, Pakom Pelatihan Pengoperasian Komputer Bagi Perangkat Desa Di Kecamatan Gondangrejo Kabupaten Karanganyar, WARTA LPM, Vol. 20, No. 2, September 2017: 111-114

[4] Jogiyanto, HM. Pengenalan Komputer, Dasar Ilmu Komputer, Pemrograman, Sistem Informasi dan Intelegensi Buatan, Andi Yogyakarta 2001.

[5] Oktaf Juairiyah, Hendrixon, Penerapan E-Office Dalam Administrasi Perkantoran (Studi Kasus : Balitbangda Prov. Sumsel), Jurnal Pembangunan Nagari Volume 2 Nomor 1 Edisi Juni 2017 